\title{
Learning Styles and Academic Achievement in College Students from Buenos Aires
}

\author{
Agustín Freiberg Hoffmann ${ }^{1}$, Juliana Beatriz Stover ${ }^{1}$, Fabiana Uriel ${ }^{2} \&$ María Mercedes Fernández Liporace ${ }^{1}$ \\ ${ }^{1}$ School of Psychology, University of Buenos Aires, National Council of Scientific and Technical Research, \\ Buenos Aires, Argentina \\ ${ }^{2}$ School of Psychology, University of Buenos Aires, Buenos Aires, Argentina \\ Correspondence: Agustín Freiberg Hoffmann, School of Psychology, University of Buenos Aires, National \\ Council of Scientific and Technical Research, Buenos Aires, Argentina. Tel: 54-011-4952-5490. E-mail: \\ afreiberg@psi.uba.ar
}

Received: July 7, 2015 Accepted: August 9, 2015 Online Published: August 13, 2015

doi:10.5539/ijps.v7n3p141 URL: http://dx.doi.org/10.5539/ijps.v7n3p141

\begin{abstract}
Learning styles analyze cognitive-intellectual aspects participating in every learning situation (Curry, 1983). The study describes the behavior of this concept in 300 college students of various degree courses (Biology, Industrial Engineering, Law, Nutrition, Psychology, and History of Art). Goals aimed at the analysis of learning styles according to personal and academic variables-gender, age, major and academic achievement, as well as the assessment of each style's ability to predict the students' achievement. Results showed a general medium preference for every style in students of every degree course. Pragmatist style was manifested in males and in younger students. Converging style was remarkable in Engineering, as well as Nutrition and Biology students, compared to Psychology and History of Art. Analyzing styles by academic achievement, significant differences in Assimilating and Converging types were verified in Biology high-achievers. Finally, academic achievement was explained by a regression model where every learning style participates as a predictor. Results are discussed on a theoretical basis as well as considering practical outcomes.
\end{abstract}

Keywords: academic achievement, CHAEA, college students, Kolb, learning styles

\section{Introduction}

Improving the access to college and learning quality, as well as increasing the number of graduates arise as urgent challenges for next years' education all over the world (UNESCO, 2009).

Data from local universities indicate a continuous increase of tuitions, reflected by an average rate of annual growing of $2.5 \%$ between 2000 and 2010. However, colleges report a decrease in academic achievement and a rising dropout rate. According to estimations, 58\% of freshmen in Argentina drop out college or change their degree course. Moreover, degree courses with syllabi planned to be finished in six years are commonly extended to eight years. $22.68 \%$ of applications to public universities correspond to new applicants, while the remaining $77.32 \%$ involve re-applications motivated by diverse causes. Furthermore, authorities form several public universities inform that only $25 \%$ of freshmen obtain a degree, data sustained by official statistics (Clarín, 2012; Giménez, 2012; Ministerio de Educación, 2010; Pinto, 2012).

This issue is being focused by studies which analyze academic achievement as related to different variables, hypothesized as determinants. Tejedor Tejedor (2003) proposed a classification of these factors into five major categories, named as identification variables (sex, age, marital status), psychological (abilities, learning strategies, learning styles, personality, among others), academic (previous academic achievement, class attendance), didactic (formats of evaluation, learning tracking), as well as social and linked to the family variables (maximum level of studies achieved by parents, residence, family group).

This study aims at analyzing the notion of learning styles related to academic achievement in college students from Buenos Aires, through psychological variables. 


\subsection{Learning Styles}

The concept of learning styles allows the examination of cognitive-intellectual elements participating in every learning situation, based on the information process classical model, which includes concepts such as orientation, sensorial loading, short-term memory, enhanced associations, coding system, and long-term storage (Curry, 1983). Research on this subject has been developed under two different approaches: one analyzes styles individually, while the other does it holistically, as part of a cycle. The first one links the ability to acquire new knowledge with the possession of a specific style, as a result of the combination of diverse activities and strategies. This perspective poses different and autonomous styles, with some of them facilitating learning in a given situation, and others hindering it. On the other hand, the second approach introduces the idea of the learning cycle, associating the ability to acquire and assimilate new information with the preference to process it through a series of steps. This approach assumes that the style configuration is determined by the type of cognitive operations and their harmonious functioning in every individual. Moreover, it stresses the need to exhibit a particular structure of styles in order to assimilate specific information without major impediments.

The paper focuses on the second approach, counting Kolb (1976) as one of its main authors, as well as Honey and Mumford (1986), who understand the generation of knowledge as determined by the transformation of perceived experience. This process takes place departing from two components, one grasping experience and the other identified as the transforming experience (Kolb, 1984). The first component is related to the grasping and conceptualization of experience, and the second is linked to the thinking and verification of new information. Meanwhile, each dimension is integrated by two dialectical processes, which could be understood as phases participating in every learning situation. Thus, there is a correspondence between the grasping experience component, the Concrete Experience (CE) and the Abstract Conceptualization (AC). Reflexive Observation (RO) and Active Experience ( $A E$ ) match with the transforming experience component. These four instances have an impact on the acquisition of new knowledge by means of a continuous cycle. According to this, at the beginning students assimilate the experience (CE), going on with reflection (RO), which later will allow them to relate new contents with the previous ones, permitting their conceptualization (AC). Resulting concepts will be empirically tested, to confirm them (or not), then deciding their conservation, modification or elimination (AE) (Kolb \& Kolb, 2009).

A class example can be examined to improve comprehension of the way this cycle takes place. During the class the student perceives contents transmitted by teachers (CE), starting a reflexive activity which will be supported once the class finishes (RO). Later, bibliographic contents are added, starting a conceptualization process to relate new and previous information (notes, reading, theorizations already known, contents from diverse subjects, etc.) (AC). Finally the student must test if he/she achieved this new acquisition at the exam, verifying its adequacy by means of the grade obtained (AE). At this point two possible scenarios arise; the first one is failure, which should prompt the student to review the bibliography in depth, ask for teachers' guidance or help, repeating later the former sequence. The second scenario, based on passing the exam, could end the learning cycle right there, or perhaps the student could choose to ask for a consultation with teachers to clear doubts about contents, or even developing a self-evaluation, alternative which also would repeat the sequence.

Kolb states that, even if this cycle is developed by every person in learning situations, the model described before seems ideal and not necessarily identically reproduced for each individual in every occasion. Those differences are determined by the degree in which each one of the processes above mentioned manifests in each student. Furthermore, these discrepancies will decide the type of learning style which predominates in each student, and they allow responding the question about how individuals participating in the same learning situation assimilate different magnitudes of information (Honey \& Mumford, 1986). Hence, two positions are settled. On one hand, Kolb (1984) proposes four learning styles, which depend on the interaction of the four processes. This way, persons can be described as accommodators (CE and $\mathrm{AE}$ ), convergers (AC and $\mathrm{AE}$ ), divergers (CE and RO) and assimilators (AC and RO). On the other hand, Honey and Mumford (1986) and later Alonso, Gallego and Honey (1994) took styles and processes as synonyms, relabeling them as, active (active experience), reflexive (reflexive observation), theoretical (abstract conceptualization), and pragmatic (active experimentation).

\subsection{Learning Styles and Academic Achievement}

Each discipline involves contents, methods, information and specific demands. Their acquisition by students becomes easier when style configuration is similar to that required by every degree course. Thus, it is expected that students with styles which are different from those specific of the features in the degree course, could be 
able to modify their preferences to learn while they go forward in their academic paths (Bahamón Munetón, Vianchá Pinzón, Alarcón Alarcón, \& Bohórquez Olaya, 2012).

Research linking styles to academic achievement analyzes, in general, the relationship between different styles and college performance. Therefore, academic success seems to depend on the distance between the specific styles combination demanded by each degree course and the configuration exhibited by each student (Kolb, 1976). Following this idea, two groups of studies have been developed. It is assumed that there is a distinctive style for every expertise area; if it matches with those present in the student, the learning process will be easier (Kolb, 1984). On the contrary, the second group of studies associates success in learning with a harmonic functioning of all styles, reached when all of them are developed in the same proportion (Alonso, Gallego, \& Honey, 1994; Honey \& Mumford, 1986).

According to what was previously stated, this study aims at the following goals: a) to describe the degree of preference exhibited by a sample of Argentinean college students from different majors for each learning style here considered, b) to examine possible statistically significant differences in styles by gender, age, and degree course, c) to analyze statistically significant differences in styles by high or low academic achievement in each major, and d) to test the ability of every style to predict academic achievement.

These results will lead to a better comprehension of specific features in our students, allowing the adaptation of teaching methods to get better achievements and more successful learning processes.

\section{Method}

\subsection{Design}

A transversal and descriptive-inferential design (group differences and predictive) was employed. Data were gathered using a simple-intentional sampling (Miles \& Banyard, 2007; Scheaffer, Mendenhall, \& Lyman Ott, 2007).

\subsection{Instruments}

\subsubsection{Personal and Academic Survey: Enquires about Personal and Academic Data}

Personal variables: gender, age.

Academic variables: a) major, b) time elapsed from the beginning of the college course, c) amount of classes passed. These last two data were used to calculate academic achievement in a wide sense, as success (passing a class, course or degree in a certain period of time) or delay (concerning the time officially established) (Tejedor Tejedor, 2003). This notion of academic achievement seems appropriate for this study since every major included in the sample is framed into the National Law of Higher Education. That law establishes the requirement of passing at least two classes a year, given that these majors are designed to last for at least four years. This allows calculating achievement for every major in the same way, by the ratio between the number of passed classes and the number of years elapsed from starting college. The result obtained is an index which correlates positively with academic achievement (De Miguel \& Arias, 1999). This methodology is, certainly, arguable as many others are, and it is one in various ways of analyzing achievement. It would be mistaken to assume this measure represents accurately academic achievement, because this concept involves multiple dimensions, such as satisfaction, dropout rate, average time estimated to achieve a degree, efficacy rate, success rate, among others (Martín, García, Torbay, \& Rodríguez, 2008). For this reason, in this study as in many others, this measure represents a partial aspect in the phenomenon and it must be interpreted cautiously.

2.2.2 Honey-Alonso Questionnaire of Learning Styles - CHAEA as Its Spanish Acronym-(Alonso, Gallego, \& Honey, 1994)

A version adapted to college students from Buenos Aires was employed (Freiberg Hoffmann, \& Fernández Liporace, 2013). This short scale is composed by 28 dichotomous items responded by agreement $(+)$ or disagreement (-) regarding each assertion. CHAEA assesses four learning styles: three of them belonging to Kolb's model (Assimilating, Converging, Accommodating), and one posed by Alonso et al. (1994) (Pragmatist style). There is no time limit for response. Noteworthy to clarify that the expression questionnaire is being used in a wide sense, following the original authors, even if the scale is composed of propositions and not by questions.

\subsection{Participants}

The sample consisted of 300 college students from Buenos Aires (24.7\% males; $75.3 \%$ females) with ages varying from 20 to 35 years ( $\bar{X}_{\text {Age }}=24.43 ; S D=2.84$ ), range that, according to official statistics, include $80 \%$ of college population (Universidad de Buenos Aires, 2011). Examinees were in the middle of their courses, 
requiring they be attending at least the third year of their studies. The sample included homogeneous numbers of students $(n=50)$ from six different degree courses (Biology, Industrial Engineering, Laws, Nutrition, Psychology, History of Art), all of them from public universities.

\subsection{Procedures}

Data were gathered during regular classes, by a properly trained psychologist. Students participated voluntarily by signing an informed consent, and without economic retribution. Results confidentiality and anonymity were assured at every moment, declaring the feasibility of ceasing responses at any time. Institutional endorsements approved the study.

\subsection{Data analysis}

Data were analyzed using SPSS 21 (IBM Corporation, 2012). Since data observed normality and homoscedasticity assumptions compliance, parametric tests were calculated. Besides, an adequate statistical power of the analyses was ensured by estimating the effect size, considering the cut-off values established by Cohen (1977).

\section{Results}

Following CHAEA's designers (Alonso et al., 1994), firstly 5 percentile ranges for every style were established from raw scores, in order to express the degree of preference of the student towards each style: low (L), medium-low (ML), medium (M), medium-high (MH), high (H) (Table 1).

Table 1. Learning styles preferences according to raw scores

\begin{tabular}{|c|c|c|c|c|c|}
\hline Learning Styles & $\begin{array}{c}\text { Low } \\
(\mathrm{P}<20)\end{array}$ & $\begin{array}{c}\text { Medium-Low } \\
\text { (P 20-39) }\end{array}$ & $\begin{array}{l}\text { Medium } \\
\text { (P 40-59) }\end{array}$ & $\begin{array}{l}\text { Medium- High } \\
\text { (P 60-79) }\end{array}$ & $\begin{array}{c}\text { High } \\
(\mathrm{P} \geq 80)\end{array}$ \\
\hline Assimilating & 0 to 5 & 6 & 7 & 8 & $9-10$ \\
\hline Accommodating & 0 to 2 & 3 & & 4 & 5 \\
\hline Converging & 0 to 2 & 3 & 4 & 5 & $6-7-8$ \\
\hline Pragmatist & \multicolumn{2}{|r|}{0} & 1 & 2 & $3-4-5$ \\
\hline
\end{tabular}

After conducting the studies above reported, means and standard deviations of learning styles were calculated for every degree course-group. They were classified according to the categories proposed in Table 1, by means of 5 levels.

No preference of style was observed in any degree course, being all of them present in every discipline in a remarkable way (Table 2). So, medium, medium-high and high levels were exhibited, except by the Accommodating style for Nutritionists, where the preference was medium-low. A noteworthy preference of the Converging style was observed in Law students, as seen in Figure 1.

Table 2. Predominant styles by major

\begin{tabular}{lccccc}
\hline \multirow{2}{*}{ Major } & & \multicolumn{4}{c}{ Style } \\
\cline { 3 - 6 } & & Assimilating & Accommodating & Converging & Pragmatist \\
\hline \multirow{2}{*}{ Biology } & $\bar{X}$ & 8.10 & 4.02 & 4.84 & 1.46 \\
& $S D$ & 1.78 & 1.15 & 1.55 & 1.23 \\
Preference & & $\mathrm{MH}$ & $\mathrm{M}-\mathrm{MH}$ & $\mathrm{MH}$ & $\mathrm{M}$ \\
Industrial & $\bar{X}$ & 7.88 & 3.90 & 5.52 & 1.78 \\
Engineering & $S D$ & 1.42 & 1.32 & 1.75 & 1.43 \\
Preference & & $\mathrm{MH}$ & $\mathrm{M}-\mathrm{MH}$ & $\mathrm{H}$ & $\mathrm{MH}$ \\
\multirow{2}{*}{ Law } & $\bar{X}$ & 7.46 & 3.80 & 7.68 & 1.74 \\
& $S D$ & 1.86 & 1.74 & 1.88 & 1.24 \\
\hline
\end{tabular}




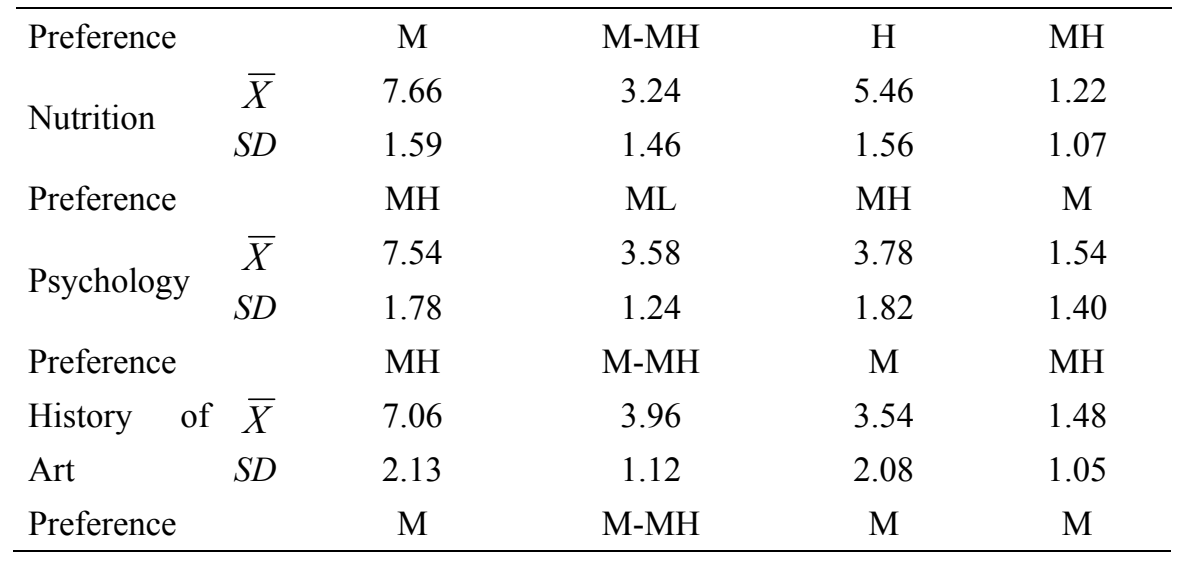

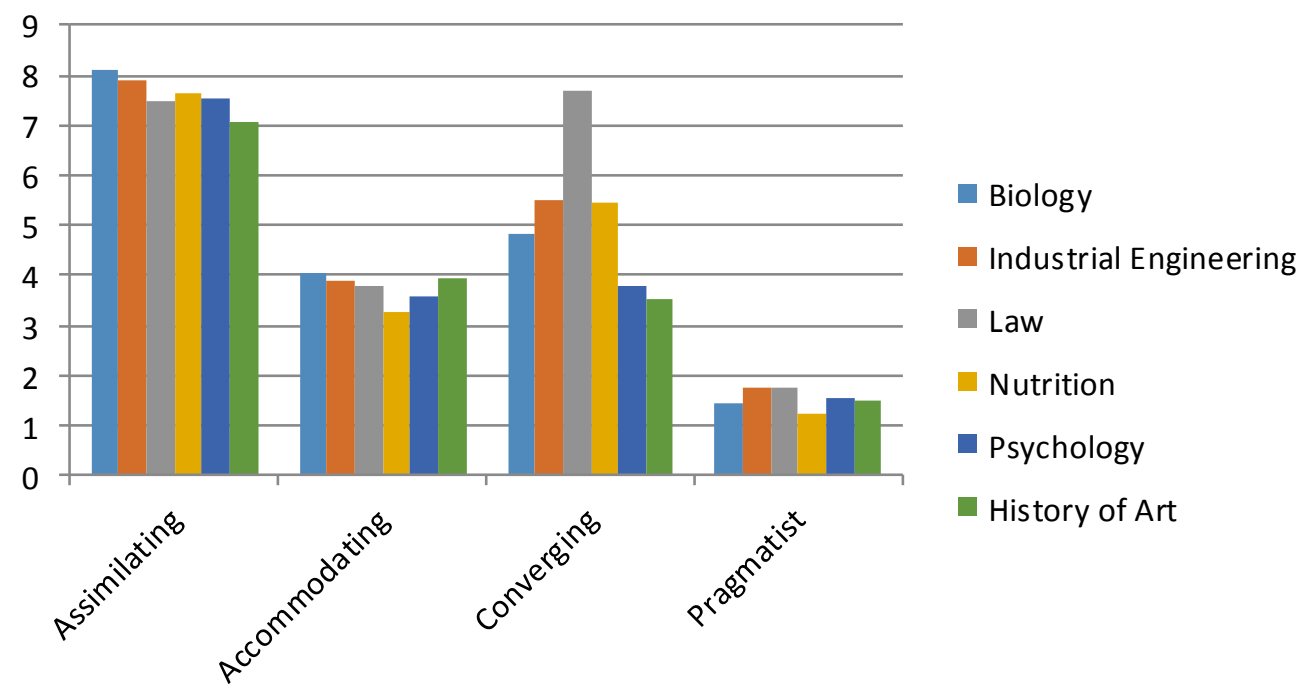

Figure1. Means for learning styles by major

Next, the sample was split into halves according to two general specializations-Exact and Biological Sciences-Technological Disciplines versus Social-Human Sciences-, performing the same calculations.

When grouping college students of Exact and Biological Sciences-Technological Disciplines (Biology, Industrial Engineering) exceeded learning preferences showed by the students of Social-Human Sciences (Law, Nutrition, Psychology, History of Art) in every style (Figure 2). When classifying styles by preference range- low, medium-low, medium, medium-high, high — only Assimilating and Pragmatist exhibited different positions in each one of the two specialization areas (Table 3).

Table 3. Predominant styles by specialization area

\begin{tabular}{cccccc}
\hline \multirow{2}{*}{ Specialization area } & & \multicolumn{4}{c}{ Style Preference } \\
\cline { 3 - 6 } & & Assimilating & Accommodating & Converging & Pragmatist \\
\hline Exact-Technological & $\bar{X}$ & 8 & 4 & 5.18 & 1.62 \\
$(n=100)$ & $S D$ & 1.61 & 1.23 & 1.68 & 1.33 \\
& & MH & M-MH & MH & MH \\
& & & & & \\
Social-Human Sciences & $\bar{X}$ & 7.43 & 3.64 & 4.36 & 1.49 \\
$(n=200)$ & $S D$ & 1.85 & 1.26 & 1.98 & 1.20 \\
& & $\mathrm{M}$ & $\mathrm{M}-\mathrm{MH}$ & $\mathrm{MH}$ & $\mathrm{M}$ \\
\hline
\end{tabular}




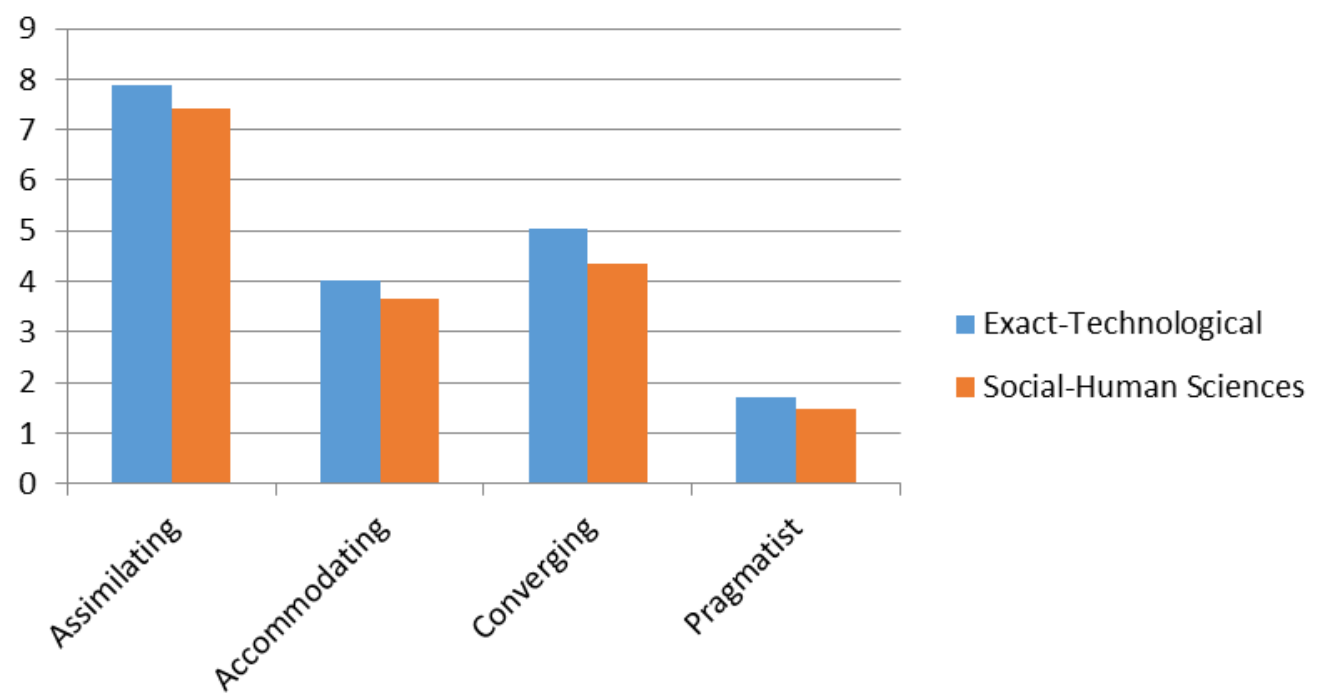

Figure 2. Means for learning styles by specialization area

As for the study of styles by personal variables, Student's $t$ tests for independent samples were calculated. A statistically significant difference by gender $(\mathrm{p}<.01)$ was found, favoring males $\left(\bar{X}_{\text {males }}=1.88, S D=1.44\right.$; $\left.\bar{X}_{\text {females }}=1.42, S D=1.16\right)$ with a low effect size $(d=.35)$.

Concerning age, the sample was divided into two groups by the 50th percentile, separating ranges from 20 to 24 years on one hand, and from 25 to 35 years old, on the other. Results showed a significant difference $(\mathrm{p}<.05)$ favoring younger students in Pragmatist style $\left(\bar{X}_{20-24}=1.66, S D=1.28 ; \bar{X}_{25-35}=1.34, S D=1.19\right)$ with a small effect size $(d=.26)$.

Going on with the analysis of differences in styles, they were examined by degree course calculating ANOVA One-Way with Tukey's post-hoc tests since the number of groups to be contrasted was higher than 5 , all of them of the same size (Cohen, 2008). Additionally eta square $\left(\eta^{2}\right)$ was calculated in order to estimate the effect size. Table 4 resumes differences in the Accommodating style favoring Biology and History of Art students, compared to Nutrition's, with a low and medium effect size $\left(\eta^{2}=.045\right)$. Converging style also showed differences, but now favoring students of Industrial Engineering, Nutrition and Biology in comparison to Psychology and History of Art students. Besides, History of Art's differentiated from Law students, favoring the last group with a large effect size $\left(\eta^{2}=.134\right)$.

Table 4. Learning styles. Differences by major

\begin{tabular}{cccccc}
\hline \multirow{2}{*}{ Major } & & \multicolumn{5}{c}{ Learning Style } \\
\cline { 2 - 6 } & & Assimilating & Accommodating & Converging & Pragmatist \\
\hline Biology & $\bar{X}$ & 8.10 & $4.02^{\mathrm{B}}$ & $4.84^{\mathrm{C}}$ & 1.46 \\
$(n=50)$ & $S D$ & 1.79 & 1.15 & 1.56 & 1.23 \\
& $\bar{X}$ & 7.88 & $3.90^{\mathrm{AB}}$ & $5.52^{\mathrm{C}}$ & 1.78 \\
Industrial Eng. & & 1.33 & 1.75 & 1.43 \\
$(n=50)$ & $S D$ & 1.42 & $3.80^{\mathrm{AB}}$ & $4.68^{\mathrm{BC}}$ & 1.74 \\
Law & $\bar{X}$ & 7.46 & 1.11 & 1.89 & 1.24 \\
$(n=50)$ & $S D$ & 1.86 & $3.24^{\mathrm{A}}$ & $5.46^{\mathrm{C}}$ & 1.22 \\
Nutrition & $\bar{X}$ & 7.66 & 1.46 & 1.57 & 1.07 \\
$(n=50)$ & $S D$ & 1.60 & & & \\
\hline
\end{tabular}




\begin{tabular}{clcccc}
\hline Psychology & $\bar{X}$ & 7.54 & $3.58^{\mathrm{AB}}$ & $3.78^{\mathrm{AB}}$ & 1.54 \\
$(n=50)$ & $S D$ & 1.79 & 1.24 & 1.82 & 1.40 \\
Art History & $\bar{X}$ & 7.06 & $3.96^{\mathrm{B}}$ & $3.54^{\mathrm{A}}$ & 1.48 \\
$(n=50)$ & $S D$ & 2.13 & 1.12 & 2.08 & 1.05 \\
$F$ & & 2.038 & 2.787 & 10.758 & 1.347 \\
Sig. & & .073 & .018 & .000 & .244 \\
$\eta^{2}$ & & .033 & .045 & .155 & .022 \\
\hline
\end{tabular}

Note. Different letters indicate statistically significant differences between groups.

In order to analyze styles by academic achievement and major, the metric variable academic achievement was calculated taking into account the number of passed classes and the number of years elapsed from the admission to college (De Miguel \& Arias, 1999). Later, this variable was categorized as high and low achievement taking the 50th percentile as a cut-off point. Student's $t$ tests were calculated in order to examine possible significant differences in styles by academic achievement (high and low), verifying such differences $(p<.05)$ only for Biology students, regarding Assimilating style $\left(\bar{X}_{\text {LowAA }}=7.53, S D=1.86 ; \bar{X}_{\text {HighAA }}=8.70, S D=1.51\right)$ with a moderate effect size $(d=.69)$, and the Converging style $\left(\bar{X}_{\text {LowAA }}=4.42, S D=1.53 ; \bar{X}_{\text {HighAA }}=5.29, S D=1.49\right)$ also with a moderate effect size $(d=.58)$, both favoring high-achievers.

To test the influence of each style on academic achievement in the whole sample, a multiple linear regression model was posed. Every style was included initially. Parameters were calculated by least squares method through the sequential stepwise backwards elimination procedure. The continuous variable academic achievement was calculated by the ratio between the number of passed classes and the number of years elapsed from starting college (De Miguel \& Arias, 1999).

The analysis was performed following procedures suggested by various authors (Álvarez Cáceres, 2007; Davey \& Savla, 2010; Pedroza \& Docovskyi, 2006). First, the dependent variable (academic achievement) was explored looking for outliers, which could alter results. One case was found and removed. Later the model goodness of fit was tested using $R^{2}$ as an effect size indicator, the corrected $R^{2}$ as an index of the total variance explained by the model - since it offers corrected values preserving parsimony and avoiding the sample size influence (Gil Pascual, 2011) - and the standard error magnitude, expecting that it would be under 1.96, limit established for a 5\% significance level (Álvarez Cáceres, 1995; Gutiérrez, 2007). $R^{2}$ indicated low and moderate effect size $\left(R^{2}=.045\right)$. Corrected $R^{2}$ found the estimated model explained $3.2 \%$ of academic achievement variance by means of the four styles, being standard error (.872) inside the acceptable interval for a good fit. The least standard error is, the more favorable predictions of the model will be, due to a better fit of the regression line to the scatter plot.

The assessment of the model fit continued with the exam of ANOVA statistics, employed to examine the total significance of estimated parameters, in order to determine the existence of a linear relation between the dependent variable and all the independent ones. Thus, this relation was verified $(p<.01)$.

After conducting the above studies, residuals were examined to verify non-autocorrelation assumptions compliance, as well as to establish the multicollinearity diagnostics and equality of variances, because they allow the determination of the estimated model fit to empirical data, and to detect models wrongly specified (Xin \& Xiao Gang, 2009). As for non-autocorrelation, Durbin-Watson test was carried out, with patterns varying between 0 and 4, assuming the independence of residuals since they were between 1.5 and 2, verifying non-selfcorrelation (1.869). The criterion of multicollinearity was examined by means of condition indices and variance inflation factors (VIF), where the first ones must be lower than 30 , and the second ones, lower than 10 (Table 5). Equality of variances was studied by means of a standardized residual plot. Results showed these assumptions compliance and hence, the good model fit. 
Table 5. Multicollinearity indices

\begin{tabular}{lcc}
\hline \multicolumn{1}{c}{ Model } & Condition Indices & VIF \\
\hline Assimilating & 3.563 & 1.075 \\
Converging & 5.476 & 1.103 \\
Accommodating & 8.996 & 1.054 \\
Pragmatist & 14.160 & 1.015 \\
\hline
\end{tabular}

Finally, coefficients exam offered more detail about the effect of each exogenous variable on the endogenic. $B$ supplied information about the rate expected for academic achievement variation according to each predictor variable. Beta coefficient was used to appreciate the magnitude of participation of each independent variable in the prediction of the dependent variable variability, weighting its relative importance in the model. Student's $t$ test allowed assessing if the effect of predictors on the explained variable was statistically significant, or not ( $p$ $<.05)$. Table 6 shows that, even maintaining four styles initially proposed as explanatory variables - Converging, Assimilating, Accommodating, Pragmatist-, only two of them-Converging and Pragmatist-explained significantly $(\mathrm{p}<.05)$ the variability of academic achievement. Beta coefficients showed a relative relevance in estimated parameters for both dimensions, with the Converging style contributing with $14.4 \%$ of its variability to explain the dependent variable, and with the Pragmatist style, contributing with $12.9 \%$. Additionally, the positive relation of $B$ values manifested a direct relationship between variables, indicating that by every point gained in Converging and Pragmatist style, achievement increases .066 and .091 points in every case. The fact of these values keeping a difference higher than the double of their errors shows the high significance of those parameters.

Table 6. Regression coefficients for the model

\begin{tabular}{lcccccc}
\hline \multicolumn{1}{c}{ Model } & $B$ & $95 \% \mathrm{CI}$ & Standard Error & Beta & $t$ & Sig. \\
\hline (Constant) & 2.318 & {$[1.75,2.88]$} & .288 & & 8.056 & .000 \\
Assimilating & .028 & {$[-.03, .08]$} & .029 & .056 & .952 & .342 \\
Converging & .066 & {$[.01, .12]$} & .028 & .144 & 2.404 & .017 \\
Accommodating & .000 & {$[-.08, .08]$} & .041 & -.001 & -.009 & .993 \\
Pragmatist & .091 & {$[.01, .17]$} & .041 & .129 & 2.241 & .026 \\
\hline
\end{tabular}

\section{Discussion}

\subsection{Summary of the Study}

The study, developed in a sample of 300 college students from Buenos Aires, aimed at describing the degree of preference for each learning style here considered, as well as to examine possible differences by gender, age, and degree course. Besides, it analyzed differences in styles by high or low academic achievement in each major, and tested the ability of every style to predict academic achievement.

The sample included homogeneous numbers of students attending six different degree courses (Biology, Industrial Engineering, Laws, Nutrition, Psychology, History of Art), all of them from public universities.

The ultimate goal pursues the better comprehension of specific features in our students, later on leading academic institutions to adapt teaching methods in order to get better achievements and more successful learning processes.

\subsection{Implication on the Knowledge/Learning Process/Theory}

The approach assumed in the study conceives learning styles are part of the learning cycle. This cycle determines the appropriate knowledge assimilation (Alonso, Gallego, \& Honey, 1994; Honey \& Mumford, 1986; Kolb, 1984). Its harmonic functioning requires the presence of certain mental processes which are not necessarily 
developed in an equivalent way in every student. However, these processes do need to be present in some measure in order to let the correct development of every step in the cycle.

Noteworthy to remember is that the system employed in the study classified the preference for every style by means of five ordinal categories: low, medium-low, medium, medium-high and high. Generally speaking, results showed the presence - moderate to high of every style - Converging, Assimilating, Accommodating, Pragmatistin students from every degree course, except for Nutritionists, where the Accommodating style was classified as medium-low. These findings run in the same direction of those reported by previous research, where significant differences by specific majors were not verified (Lasitha, Tharanga, Chaturaka, \& Senaka, 2013; Ruiz Ruiz, Trillos Gamboa, \& Morales Arrieta, 2006). According to Alonso et al. (1994) each style is related to every stage of the learning process such as, having an experience, reviewing the experience, concluding from the experience and planning the next steps. When preferences are distributed among all styles and not centered only in one of them, the notion of flexibility for learning comes up: the student is able to assimilate information under diverse circumstances. When, on the other hand, preference rests on a single style, developing the remaining ones becomes imperative to improve learning.

Findings exposed here are, of course, restricted to third-year college students and onwards. That fact brings about two different interpretations. On one hand, it seems reasonable to conclude that students included in the sample reached the third year because of the equivalent development in their styles. Thus, this balance could be useful for learning scenarios, allowing students to stay into the system. Conversely, a possible hypothesis about students with unbalanced styles might pose that those individuals were not included in the study simply because of dropout, academic failure or by changing their degree courses. On the other hand, however, it seems logical to assume that successful students accomplished the implicit goal of enhancing their four styles, gradually improving the weaker ones while continuing with their degree courses (Canalejas Pérez, Martínez Martín, Pineda Ginés, Vera Cortés, Soto González, Martin Marino, \& Cid Galán, 2005; Madrid Valdebenito, Acevedo Pierart, Chiang Salgado, Motecinos Palma, \& Reinicke Seiffert, 2009). Nevertheless, to the contrary of the above mentioned, students from the Nutritionists group manifested a medium-low level of the Accommodating style. Apparently at this stage of their learning cycles this result would imply that the distinction found does not seem to have an impact on their achievement, possibly being an isolated result.

In general terms, authors (e.g., Carvajal Olaya, Trejos Carpintero, \& Barros Bernal, 2007) promote the harmonic development of styles as a strategy to improve learning quality, stimulating those which are under the level reached by the rest of them. The preference for various styles provide more and better resources, thus allowing the use of a wider range of means, strategies and tools to incorporate specific contents from different disciplines, with independence of teaching methods adopted by each teacher (Gravini Donado, Cabrera Pérez, Avila Molina, \& Vargas González, 2009). The teaching-learning process habitually does not consider potential individual issues or, at least, that seems to be the fact in most cases. The teacher's reluctance and/or inability to adapt his/her method to each student require from the latter the development of every learning style, in order to adapt and face any possible method, content, and situation.

Following Dale (1969) the more number of styles employed by the student, the higher the percentage of information likely to be retained will be. Thus, students handling a single style retain just $20 \%$ of the information presented, while those who balance their preference within the four styles would be able to get $90 \%$ of contents. Even though some authors (Fazey \& Marton, 2002; Kolb, 2006; Reese, 1998) have addressed this hypothesis, there is no appropriate evidence to test it, opening the field to further research (see 4.4).

Setting aside the analysis by degree courses, and trying to examine wider categories, it is interesting to pay attention to major degree course grouped by specialization areas. Thus, the categorization (Exact-Biological Sciences-Technological versus Social-Human Sciences) posed here -in view of the sample compositionhighlights slightly higher scores in every learning style for the first major discipline. Furthermore, since Assimilating and Pragmatist styles are evaluated as medium-high in the first group, both styles are situated into the medium range for the Social-Human group. Considering this when examining the theoretical hypothesis on this matter (Alonso et al., 1994; Kolb, 1976), it should be pointed out that the Assimilating style is linked to formal thinking, coherence and logical validity of ideas, describing individuals who possess it as not very sociable. Simultaneously, Pragmatist style is associated to the ability to apply insights to practical situations, acting fast when solving problems. Both styles represent features inherent to paradigmatic profiles required in students from Exact-Biological Sciences and Technological disciplines, and its higher presence in that group reproduces findings reported in previous research (Cagiltay, 2008; Morales, Alvitier, Hidalgo, García, \& Molinar, 2012; Ortiz Ojeda \& Canto Herrera, 2013). Other studies, conversely, have informed that such styles are absent 
or slightly developed in students of Social-Human majors (Concha \& López, 2009; Shukr, Zainab, \& Rana, 2013).

Analyzing differences in styles by personal variables, the predominance of Pragmatist style in males with a low effect size must be underlined. Literature on that subject has reported more reflection and theorization over empirical verification of ideas in women, whereas the opposite tendency could be observed in men (Aguilar Rivera, 2010; López Aguado, 2011). Hence, these findings go in the same direction of previous results.

Regarding age, only one statistically significant difference, with a low size effect, favoring younger students in Pragmatist style was verified. Pragmatist profiles can be described as fast to make decisions and to transform any idea into practical terms. They enjoy when developing activities in unstructured environments. It seems consistent with Kolb's assertions (Kolb, 1976), who concluded that the preference for abstract learning increases with age, while activity and pragmatism decline. That could be interesting when adapting teaching methods or syllabi, in order to increase practical activities at the first steps of every major-fact which is completely unusual in Argentinean colleges, where practical situations are presented at the second half of the academic path, when students seem to be less inclined to learn dealing with practical activities-. Theories are taught mostly in the first years, when students are predominantly pragmatic. This inconsistency could be one of the causes of early dropout, deserving a special analysis in future research (see 4.4).

Concerning differences in learning styles by major, more Accommodating profiles in students of Biology and History of Art were found, over Nutrition students. Furthermore, Converging style verified differences favoring students of Industrial Engineering, Nutrition and Biology, compared to Psychology and History of Art, as well as Law students, who exceeded the History of Art group in that style.

As for the Accommodating profile, Biology and History of Art degree courses pursue the education of students mainly in teaching and research areas, as posed in both major profiles (Facultad de Cs. Exactas y Naturales, 2014; Facultad de Filosofía y Letras, 2014). Thus, accommodating students are distinguished by their motivation to face new challenges, for experiencing situations setting aside formal-logical analyses, solving problems by trial and error, and appreciating group activities (Kolb \& Kolb, 2005) amongst other qualities desirable in future researchers (Delgado Arrieta, 2006).

Some studies (Borraci, Guthman, Rubio, \& Arribalzaga, 2008; Mohammadi \& Thaghinejad, 2014; Reza Negahi, Ghashghaeizadeh, \& Hoshmandja, 2011) have reported a strong presence of the Converging style in degree courses linked to Medicine and Engineering. This finding was underlined by a high size effect, which would allow qualifying such difference as evident and viewing some predictability in this result (Morales Vallejo, 2012). This feature is highlighted also by other authors (Delgado, Ponce, Bulnes, Escurra, \& Pequeña, 2000; Kolb \& Kolb, 2005) who, besides, describe Psychology students-and similar degree courses-as divergent (style not assessed in this study, but proposed as opposite to converging). Law students show, on the other hand, a low preference for Converging style, though higher than that manifested by History of Art students. Following these ideas, although there is no concluding evidence to justify that tendency, we can mention there are studies reporting the isolated presence of one of the two processes composing Converging style, such as active experimentation and abstract conceptualization, (e.g., Camarero Suárez, Martín del Buey, \& Herrero Diez, 2000; Valenzuela Miranda \& González Beltrones, 2010).

Examining results from style analysis on the basis of low-high academic achievement in every degree course, significant differences were verified only for students of Biology, in Accommodating and Converging styles, both favoring high-achievers. Following Kolb and Kolb (2005) Assimilating students possess logical attributes and a good handling of information, while the Converging ones are more inclined to technical issues. Both profiles agree with those proposed by the School of Exact and Natural Sciences at the University of Buenos Aires for graduates in Biology (Facultad de Ciencias Exactas y Naturales, 2014).

Next, the regression analysis conducted on the whole sample identified a model explaining $3.2 \%$ of variance in academic achievement maintaining the four styles initially proposed as predictors. The presence of every style would confirm not only the relevance of each one on academic achievement, but also the hypothesis which poses the presence of four styles (as a round process), during learning cycle. However it must be considered that not every style has shown a significant influence on the dependent variable, being only the Converging and Pragmatist styles those which predicted academic achievement in a significant way.

Hopefully these results will be useful to educational psychologists as a guide when analyzing and stimulating styles poorly developed, which could affect achievement in different majors. For instance, freshmen styles could be assessed in order to train those required by the chosen discipline. Hence, promoting styles such as Assimilating and Pragmatist in freshmen of the Exact-Biological-Technological area arises as a desirable 
didactic goal. Furthermore, it seems necessary to evaluate the preference for Pragmatic style (and eventually, to train it) in women and students older from 25 years since there is, following results, a low prevalence of it into these groups.

The preference for Converging style in students of Medicine and Engineering reported in this study as well as in previous research, suggest the evaluation of that style in applicants. It is expected to help non-converging students to develop it through special training.

Finally, worth noting that the findings reported here get the goal of describing learning profiles according to the styles approach, in order to detect students at academic risk of failure. However, this assessment must be followed by specific guidance and adaptation of teaching methods considering the conclusions discussed above, in order to improve learning quality in every case.

\subsection{Limitations}

Within limitations, the small sample size for every major comes up first $(n=50)$. It could affect results of comparative analyses, as well as those linked to the exam of styles by academic achievement. Despite of the fact that the effect size has been calculated to ensure the statistical power of results, some analyses could not be conducted because of that issue. That was the case for regression analyses by major.

Additionally, these findings cannot be generalized to every college student because participants were taking the upper third part of their major, leaving aside freshmen (see 4.4).

Considering regression models, going deeper in the analysis of the joint effect of styles on academic achievement, and examining the predictive character of styles for every degree course become matters of interest.

\subsection{Directions for Futures Studies}

Going back to results, the hypothesis which assumes that the use of more styles increases the percentage of information likely to be retained (Dale, 1969; Fazey \& Marton, 2002; Kolb, 2006; Reese, 1998) deserves to be tested. The lack of appropriate evidence to sustain it opens the field for future studies.

Concerning the relationship between the increase of age and the decline of Pragmatist style, if teaching methods or syllabi could be adapted in order to respect students' developmental features, these changes must be tested regarding their efficacy in long-term follow up. To increase practical activities at the first steps of majors, presenting abstract models to sophomores seems to be the appropriate way. However feasibility must be contemplated, as well as efficacy.

About the ability of styles to explain academic achievement, only the Converging and Pragmatist styles functioned as predictors in a significant way, but still maintaining the four styles in the model. In view of this, repeating analyses with a wider and more heterogeneous sample in terms of degree course distribution arises as the next step, in order to verify if the other two styles-Accommodating and Assimilating increase their significance levels under different conditions. Investigations also must be extended to freshmen, given that this study was conducted only with students attending third year-term and onwards.

Further studies must analyze learning styles as related to strategies and learning approaches, since these three notions seem to be strongly linked (Cano García \& Justicia Justicia, 1994).

Another research line includes de analysis of concepts such as instructional preferences or cognitive personality styles, which are complementary to learning styles. Altogether, they could be interesting and useful to examine the students' information process styles (Curry, 1983).

\section{Conclusion}

The results reported above stress the importance of learning styles in learning situations. It has been verified that freshmen (from every major included in the sample) exhibit a similar presence of every style. All of them contribute to explain academic achievement, though with different explicative power.

This information allows professionals in the educational field to identify students at academic risk, leading to develop devices to detect and enhance weaker styles. 


\section{Acknowledgments}

The study is framed into a major research with a grant by the University of Buenos Aires.

\section{References}

Aguilar Rivera, M. C. (2010). Estilos y estrategias de aprendizaje en jóvenes ingresantes a la universidad [Learning styles and learning strategies in university students]. Revista de Psicología, 28(2), 207-226. Retrieved from http://revistas.pucp.edu.pe/index.php/psicologia/article/view/1460/1407

Alonso, C. M., Gallego, D. J., \& Honey, P. (1994). Los estilos de aprendizaje. Procedimientos de diagnóstico y mejora [Learning styles. Diagnostic and improvement procedures]. Bilbao: Mensajero.

Álvarez Cáceres, R. (1995). Estadística multivariante y no paramétrica con SPSS [Multivariate and nonparametric statistics with SPSS]. Santiago de Compostela: Díaz de Santos.

Álvarez Cáceres, R. (2007). Estadística aplicada a las ciencias de la salud [Statistics applied to health sciences]. Santiago de Compostela: Díaz de Santos.

Bahamón Munetón, M. J., Vianchá Pinzón, M. A., Alarcón Alarcón, L. L., \& Bohórquez Olaya, C. I. (2012). Estilos y estrategias de aprendizaje: Una revisión empírica y conceptual de los últimos diez años [Styles and learning strategies: An empirical and conceptual review of the last ten years]. Pensamiento Psicológico, 10(1), 129-144. Retrieved from http://dialnet.unirioja.es/servlet/articulo?codigo=3971208

Borraci, R. A., Guthman, G., Rubio, M., \& Arribalzaga, E. B. (2008). Estilos de aprendizaje en estudiantes universitarios y médicos residentes [Learning styles in college students and medical residents]. EDUC MED, 11(4), 22-238. Retrieved from http://scielo.isciii.es/pdf/edu/v11n4/original3.pdf

Cagiltay, N. E. (2008). Using learning styles in engineering education. European Journal of Engineering Education, 33(4), 415-424. http://dx.doi.org/10.1080/03043790802253541

Camarero Suárez, F., Martín del Buey, F., \& Herrero Diez, J. (2000). Estilos y estrategias de aprendizaje en estudiantes universitarios [Styles and learning strategies in university students]. Psicothema, 12(4), 615-622. Retrieved from http:/www.psicothema.com/pdf/380.pdf

Canalejas Pérez, M. C., Martínez Martín, M. L., Pineda Ginés, M. C., Vera Cortés, M. L., Soto González, M., Martin Marino, A., \& Cid Galán, M. L. (2005). Estilos de aprendizaje en estudiantes de enfermería [Learning styles in nursing students]. Educación Médica, 8(2), 83-90. Retrieved from http://scielo.isciii.es/scielo.php?script=sci_arttext\&pid=S1575-18132005000200006

Cano García, F., \& Justicia Justicia, F. (1994). Learning strategies, styles and approaches: An analysis of their interrelationship. Higher Education, 27, 239-260. http://dx.doi.org/10.1007/BF01384091

Carvajal Olaya, P., Trejos Carpintero, A. A., \& Barros Bernal, A. M. (2007). Análisis estadístico multivariado de los estilos de aprendizaje predominantes en estudiantes de ingenierías de la Universidad Tecnológica de Pereira-II Semestre de 2006 [Multivariate statistical analysis of the predominant learning styles in engineering students from II semester, 2006, Technological University of Pereira]. Scientia Et Technica, 13(34), 325-330. Retrieved from http://dialnet.unirioja.es/servlet/articulo?codigo=4808093

Clarín (26 de agosto, 2012). Decanos y rectores reconocen que la alta deserción es un punto débil [Deans and chancellors recognize dropout as a weak point]. Clarín.com, Sociedad. Retrieved from http://www.clarin.com/sociedad/educacion/Decanos-rectores-reconocen-desercionpunto_0_542945805.html

Cohen, B. (2008). Explaining psychological statistics (3rd ed.). New Jersey: Wiley \& Sons.

Cohen, J. (1977). Statistical power analysis for the behavioral science. New York: Academic Press.

Concha, G., \& López, I. (2009). Estilos de aprendizaje y rendimiento teórico práctico de alumnos de imagenología, tercer año de odontología [Learning styles and theoretical-practical performance of radiology students in dentistry third year]. Int. J. Odontostomat, 3(1), 23-28. Retrieved from http://www.scielo.cl/scielo.php?script=sci_serial\&pid=0718-381X\&nrm=iso\&rep=\&lng=pt

Curry, L. (1983). An organization of learning styles theory and constructs. Paper presented at the 67th Anual Meeting of the American Educational Research Association. Montreal, Quebec. Retrieved from http://files.eric.ed.gov/fulltext/ED235185.pdf

Dale, E. (1969). Audio-visual methods in teaching (3rd ed.). New York: Holt, Rinehart \& Winston.

Davey, A., \& Savla, J. (2010). Statistical power analysis with missing data. New York: Routledge. 
De Miguel, M., \& Arias, J. M. (1999). La evaluación del rendimiento inmediato en la enseñanza universitaria [Evaluation of immediate results in university education]. Revista de Educación, 320, 353-377. Retrieved from http://www.mecd.gob.es/dctm/revista-de-educacion/articulosre320/re3201707982.pdf?documentId= $0901 \mathrm{e} 72 \mathrm{~b} 8127086 \mathrm{c}$

Delgado Arrieta, G. (2006). La dirección del personal científico: Un reto [The management of scientific staff: A challenge]. Boletín Científico Técnico INIMET. Retrieved from http://www.redalyc.org/articulo.oa?id=223018924009

Delgado, A., Ponce, C., Bulnes, M., Escurra, L., \& Pequeña, J. (2000). Relación entre necesidad cognitiva y estilos de aprendizaje en estudiantes de la U.N.M.S.N. Revista de Investigación en Psicología, 3(2), 9-18. Retrieved from http://ateneo.unmsm.edu.pe/ateneo/bitstream/123456789/2031 $/ 1 /$ revista_de_investigacion_en_psicolog\%C3\%ADa01v3n2_2000.pdf

Facultad de Cs. Exactas y Naturales. Universidad de Buenos Aires. (2014). Objetivos de la carrera [Major aims]. Retrieved from \&desarrollo $=0 \&$ id_caja $=86 \&$ nivel_caja $=2$

Facultad de Filosofía y Letras. Universidad de Buenos Aires. (2014). Plan de estudios [Syllabus]. Retrieved from http://historia.filo.uba.ar/content/presentaci\%C3\%B3n-de-la-carrera-0

Fazey, J. A., \& Marton, F. (2002). Understanding the space of experiential variation. Active Learning in Higher Education, 3, 234-250. http://dx.doi.org/10.1177/1469787402003003004

Freiberg Hoffmann, A., \& Fernández Liporace, M. M. (2013). Cuestionario Honey-Alonso de Estilos de Aprendizaje: Análisis de sus propiedades psicométricas en estudiantes universitarios [Honey-Alonso Learning Styles Questionnaire: An analysis of its psychometric properties in college students]. Revista Summa Psicológica UST, 10(1), 103-117. Retrieved from http://pepsic.bvsalud.org/pdf/summa/v10n1/a10.pdf

Gil Pascual, J. A. (2011). Metodología cuantitativa en educación [Quantitative Methodology in Education]. Madrid: UNED.

Giménez, O. (2012). Terminar una carrera universitaria lleva en promedio más de 8 años [Finishing a college degree takes on average more than 8 years]. El Día, Educación. Retrieved from http://www.eldia.com.ar/edis/20120429/terminar-carrera-universitaria-lleva-promedio-mas-anos-educacion $0 . h$ tm

Gravini Donado, M., Cabrera Pérez, E., Avila Molina, V., \& Vargas González, I. (2009). Estrategias de enseñanza en docentes y estilos de aprendizaje en estudiantes del programa de psicología de la Universidad Simón Bolivar, Barranquilla [Teaching strategies in educators and learning styles in students of the psychology program at Universidad Simón Bolívar in Barranquilla]. Revista Estilos de Aprendizaje, 3(3), 124-140. Retrieved from http://learningstyles.uvu.edu/index.php/jls/article/view/161/119

Gutiérrez, J. C. A. (2007). Estadística general aplicada [Applied general statistics]. Medellin: Fondo Editorial Universidad EAFIT.

Honey, P., \& Mumford, A. (1986). The manual of learning styles. Maidenhead, Berkshire: P. Honey, Ardingly House.

IBM Corporation. (2012). IBM SPSS Statistics. Retrieved from http://www-01.ibm.com/software/es/analytics/spss/

Kolb, D. (1976). Learning Style Inventory: Technical Manual. Boston: McBer and Company.

Kolb, D. (1984). Experiential learning: experience as the source of learning and development. New Jersey: Prentice Hall, Inc., Englewood Cliffs.

Kolb, D. (2006). The Kolb Learning Styles Inventory-Version 3.1. Hay Group. Retrieved from http://www.haygroup.com/tl/Downloads/LSI_Slides.pdf

Kolb, A., \& Kolb, D. (2005). The Kolb learning style inventory-version 3.12005 technical specifications. HayGroup. Retrieved from http://www.whitewater-rescue.com/support/pagepics/lsitechmanual.pdf

Kolb, A., \& Kolb, D. (2009). Experiential learning theory: A dynamic, holistic approach to management learning, education and development. In S. Armstrong, \& C. Fukami (Eds.), The SAGE handbook of management learning, education and development ( $\mathrm{pp}$. 1-59). California: SAGES Publications. http://dx.doi.org/10.4135/9780857021038.n3 
Lasitha, S., Tharanga, F., Chaturaka, R., \& Senaka, R. (2013). Learning styles and approaches to learning among medical undergraduates and postgraduates. BMC Medical Education, 13, 1-6. http://dx.doi.org/10.1186/1472-6920-13-42

López Aguado, M. (2011). Estilos de aprendizaje. Diferencias por género, curso y titulación [Learning styles. Differences by gender, course and qualification]. Revista Estilos de Aprendizaje, 7(7), 109-134. Retrieved from http://learningstyles.uvu.edu/index.php/jls/article/view/53/28

Madrid Valdebenito, V., Acevedo Pierart, C. G., Chiang Salgado, M. T., Motecinos Palma, H., \& Reinicke Seiffert, K. (2009). Perfil de estilos de aprendizaje en estudiantes de primer año de dos carreras de diferentes áreas en la Universidad de Concepción [Learning style of undergraduate students in two different major at the University of Concepción]. Revista Estilos de Aprendizaje, 3(3), 57-69. Retrieved from http://www.uned.es/revistaestilosdeaprendizaje/numero_3/artigos/lsr_3_abril_2009.pdf

Miles, J., \& Banyard, P. (2007). Understanding and using statistics in psychology. California: SAGE Publications, Inc.

Ministerio de Educación, Secretaría de Políticas Universitarias. (2010). Anuario 2010 [Yearbook 2010]. Estadísticas Universitarias. Retrieved from http://repositorio.educacion.gov.ar/dspace/bitstream/handle/123456789/109591/Anuario_de_Estadisticas_U niversitarias_2010.pdf?sequence $=1$

Mohammadi, I., \& Thaghinejad, H. (2014). Learning styles of nursing students in Iran using Kolb's theory: A review study. Journal of Basic Research in Medical Science, 1(1), 8-14. Retrieved from http://jbrms.medilam.ac.ir/browse.php?a_code=A-10-51-1\&slc_lang=en\&sid=1

Morales Vallejo, P. (2012). El tamaño del efecto (effect size): Análisis complementarios al contraste de medidas [Size effect: Complementary analyses for mean constrats]. Retrieved from http://web.upcomillas.es/personal/peter/investigacion/Tama\%floDelEfecto.pdf

Morales, R. A., Alvitier, L. E., Hidalgo, C. C., García, R., \& Molinar, J. E. (2012). Estilos de aprendizaje en estudiantes univesitarios de Ingeniería en Computación e Informática Administrativa [Learning styles among college students in computer engineering and administrative information technology]. Revista Estilos de Aprendizaje, 9(9), 156-168. Retrieved from http://learningstyles.uvu.edu/index.php/jls/article/view/99/64

Ortiz Ojeda, A. F., \& Canto Herrera, P. J. (2013). Estilos de aprendizaje y rendimiento académico en estudiantes de Ingeniería en México [Learning styles and academic achievement in engineering students]. Revista Estilos de Aprendizaje, 11(11), 160-177. Retrieved from http://learningstyles.uvu.edu/index.php/jls/article/view/190/151

Pedroza, H., \& Docovskyi, L. (2006). Sistema de análisis estadístico con SPSS [Statistical analysis system with SPSS]. Managua: IICA.

Pinto, M. E. (2012, 26 de marzo). En el primer año, el 58\% de los estudiantes dejan o cambian de carrera [58\% of dropout students or changing majors in their 1st year]. Clarin.com, Sociedad. Retrieved from http://www.clarin.com/sociedad/primer-estudiantes-dejan-cambian-carrera_0_670732977.html

Reese, J. H. (1998). Enhancing law students'performance: Learning style interventions. Saratoga Springs, NY: Empire State College, National Center on Adult Learning.

Reza Negahi, M., Ghashghaeizadeh, N., \& Hoshmandja, M. (2011). The study of the relationship between learning styles and thinking styles with academic self-efficacy in English lesson among the students of Islamic Azad University of Behbahan. Journal of Life Science and Biomedic, 3(1), 75-82. Retrieved from http://jlsb.science-line.com/attachments/article/20/J.\%20Life\%20Sci.\%20 Biom ed.\%203(1)\%2075-82,\%20 2013.pdf

Ruiz Ruiz, B. L., Trillos Gamboa, J., \& Morales Arrieta, J. (2006). Estilos de aprendizaje y rendimiento académico en estudiantes universitarios [Styles of learning and performance of university students]. Revista Galego-Portuguesa de Psicoloxía e Educación, 11-12(13), 441-457. Retrieved from http://ruc.udc.es/bitstream/2183/7034/1/RGP_13-28.pdf

Scheaffer, R., Mendenhall, W., \& Lyman Ott, R. (2007). Elementos de muestreo [Sample basics]. Madrid: Thomson. 
Shukr, I., Zainab, R., \& Rana, M. H. (2013). Learning styles of postgraduate and undergraduate medical students. Journal of the College of Physicians and Surgeons Pakistan, 23(1), 25-30. Retrieved from http://applications.emro.who.int/imemrf/J_Coll_Physicians_Surg_Pak/J_Coll_Physicians_Surg_Pak_2013_ 23_1_25_30.pdf

Tejedor Tejedor, F. J. (2003). Poder explicativo de algunos determinantes del rendimiento académico en los estudios universitarios [Explicative ability of some determinants of academic performance in college]. Revista Española de Pedagogía, 224, 5-32. Retrieved from http://reforma.fen.uchile.cl/Papers/Poder\%20explicativo\%20de\%201os\%20determinantes\%20del\%20rendi miento\%20en\%20los\%20estudios\%20universitarios\%20-\%20Tejedor.pdf

UNESCO. (2009). Acceso, equidad y calidad [Equity, access and quality]. Comunicado presentado en la Conferencia Mundial sobre la Educación Superior-2009: La nueva dinámica de la educación superior y la investigación para el cambio social y el desarrollo, París. Retrieved from http://unesdoc.unesco.org/images/0018/001832/183277s.pdf

Universidad de Buenos Aires. (2011). Censo de Estudiantes 2011 [Student census 2011]. Retrieved from http://www.uba.ar/institucional/censos/Estudiantes2011/estudiantes\%202011.pdf

Valenzuela Miranda, G. A., \& González Beltrones, A. V. (2010). Estilos de aprendizaje de los estudiantes de la Universidad de Sonora, México estudio de caso [Learning styles of students of the University of Sonora, Mexico case study]. Revista Estilos de Aprendizaje, 6(6), 92-102. Retrieved from http://learningstyles.uvu.edu/index.php/jls/article/view/135/95

Xin, Y., \& Xiao Gang, S. (2009). Linear regression analysis. Singapore: World Scientific. http://dx.doi.org/10.1142/9789812834119

\section{Appendix}

Note. These sentences are only presented to give the readers a general impression about the content and sense of the items employed. They were in Spanish, and this translation has been developed to include this section in the paper. Some items have been taken from the English version of the instrument (Honey and Mumford, 1986).

\section{Learning Styles Honey-Alonso Questionnaire}

\section{Instructions}

- This survey has been developed to identify the Learning Style you prefer. It is neither an intelligence test, nor it a personality test.

- You can answer it in the period of time you need. There is not a period established. It will not take you more than 15 minutes.

- There are no right or wrong answers. Results will be useful only if you respond sincerely.

- If you agree more than you disagree with some item, just write $(+)$ into brackets. If, on the contrary, you disagree more than agree, write (-).

- Please, answer every single item.

- Your name can remain anonymous.

Thank you so much.

( ) 01. I prefer to have as many sources of information as possible. The more data to think about the better.

( ) 02. I tend to reject spontaneous ideas if I cannot see them practical.

( ) 03. I thrive on the challenge of tackling something new and different.

( ) 04. I like to reach a decision carefully after weighing up many alternatives.

( ) 05. Most times I believe the end justifies the means.

( ) 06. I usually solve problems in a methodical way, and by means of a step-by-step procedure.

( ) 07. People often find me insensitive to their feelings.

( ) 08. I actively seek out new experiences.

( ) 09. I am convinced of what is right and wrong. 
( ) 10. I tend to be a perfectionist.

( ) 11. I do whatever is expedient to get the job done.

( ) 12. I believe that rational, logical thinking should prevail.

( ) 13. I enjoy when I have time to prepare and develop my work consciously.

( ) 14. In discussion groups I usually produce lots of new and spontaneous ideas.

( ) 15. If I am at team-job, I take care of methodical lines and of the agenda.

( ) 16. I like to experience and to apply things in practice.

( ) 17. In meetings I put forward practical and realistic ideas.

( ) 18. I take pride in doing a thorough job.

( ) 19. I don't mind hurting people's feelings so long as the job gets done.

( ) 20. I prefer to get straight to the point.

( ) 21. I am cautious when concluding something.

( ) 22. I love to experiment and to practice new techniques and new ideas.

( ) 23. I avoid subjective or ambiguous topics.

( ) 24. I am keen on exploring the basic principles and theories underpinning things and events.

( ) 25. I address norms and I adapt my behavior to them only of they are useful to my goals.

( ) 26. I line best practical people more than abstract and theoretical people.

( ) 27. I prefer structured things than disorganized things.

( ) 28. I do not like people who do not use a logical approach

\section{Copyrights}

Copyright for this article is retained by the author(s), with first publication rights granted to the journal.

This is an open-access article distributed under the terms and conditions of the Creative Commons Attribution license (http://creativecommons.org/licenses/by/3.0/). 